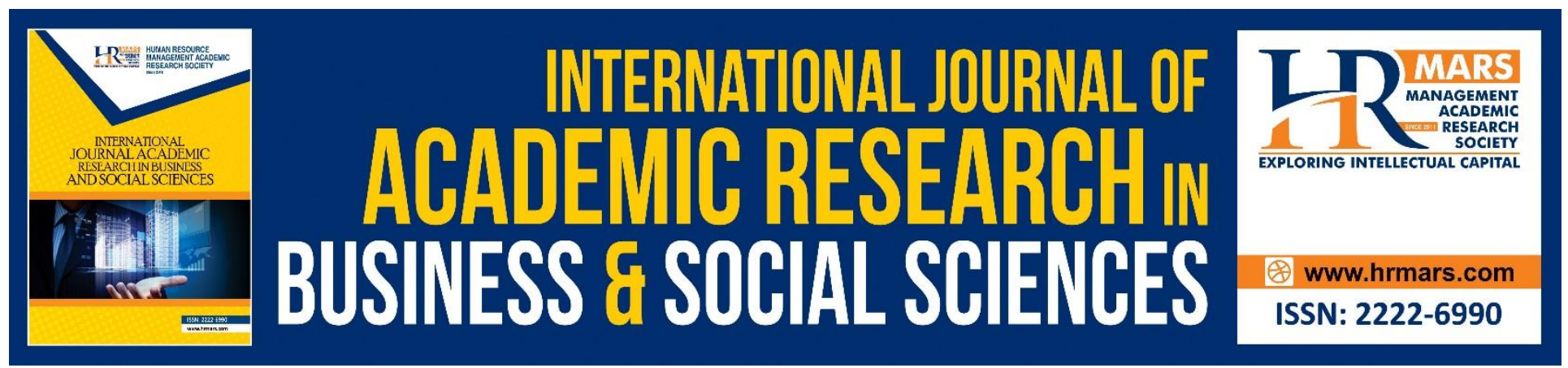

\title{
Factors Influencing Unemployment among Fresh Graduates: A Case Study in Klang Valley, Malaysia
}

Mohammad Imtiaz Hossain, Kalai Selvi A/P Yagamaran, Tanzila Afrin, Nasimuzzaman Limon, Md Nasiruzzaman, Asif Mahbub Karim

To Link this Article: http://dx.doi.org/10.6007/IJARBSS/v8-i9/4859 $\quad$ DOI: $10.6007 /$ IJARBSS/v8-i9/4859

Received: 19 August 2018, Revised: 13 Sept 2018, Accepted: 27 Sept 2018

Published Online: 02 Oct 2018

In-Text Citation: (Hossain et al., 2018)

To Cite this Article: Hossain, M. I., Yagamaran, K. S. A., Afrin, T., Limon, N., Nasiruzzaman, M., \& Karim, A. M. (2018). Factors Influencing Unemployment among Fresh Graduates: A Case Study in Klang Valley, Malaysia. International Journal of Academic Research in Business and Social Sciences, 8(9), 1494 - 1507.

Copyright: (C) 2018 The Author(s)

Published by Human Resource Management Academic Research Society (www.hrmars.com)

This article is published under the Creative Commons Attribution (CC BY 4.0) license. Anyone may reproduce, distribute, translate and create derivative works of this article (for both commercial and non-commercial purposes), subject to full attribution to the original publication and authors. The full terms of this license may be seen

at: http://creativecommons.org/licences/by/4.0/legalcode

Vol. 8, No. 9, September 2018, Pg. $1494-1507$

http://hrmars.com/index.php/pages/detail/IJARBSS

JOURNAL HOMEPAGE

Full Terms \& Conditions of access and use can be found at http://hrmars.com/index.php/pages/detail/publication-ethics 


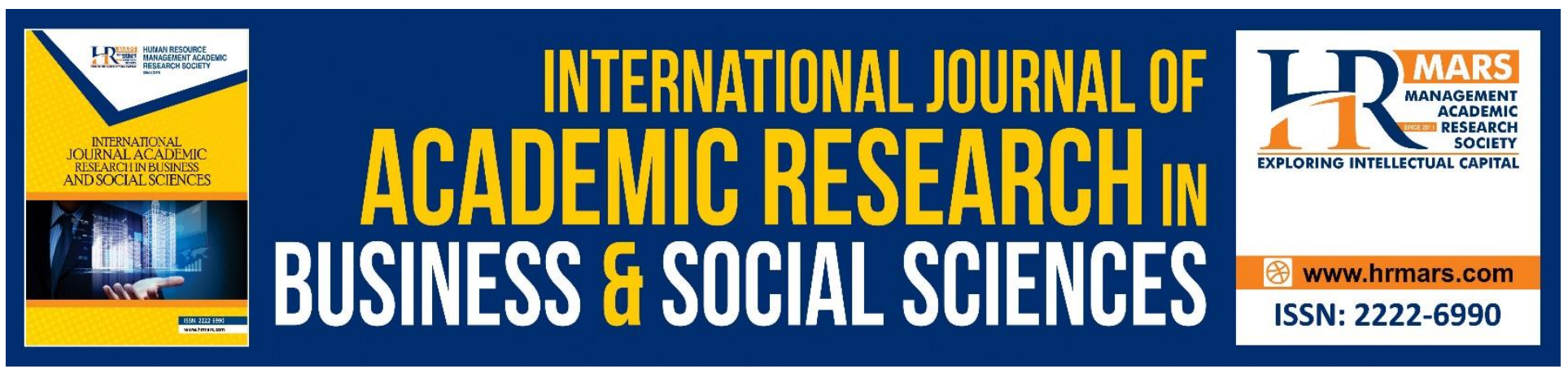

\title{
Factors Influencing Unemployment among Fresh Graduates: A Case Study in Klang Valley, Malaysia
}

\author{
Mohammad Imtiaz Hossain ${ }^{1}$, Kalai Selvi A/P Yagamaran², Tanzila \\ Afrin $^{3}$, Nasimuzzaman Limon ${ }^{4}$, Md Nasiruzzaman ${ }^{5}$, Dr. Asif Mahbub \\ Karim ${ }^{6}$ \\ ${ }^{1} \mathrm{MSc}$ in Business Economics, University Putra Malaysia, Malaysia \\ ${ }^{2} \mathrm{MSc}$ in Public Management, Binary University, Malaysia \\ ${ }^{3} \mathrm{MSc}$ in Education Management, Binary University. Malaysia \\ ${ }^{4}$ Executive Officer, NRB Commercial Bank Ltd, Bangladesh \\ ${ }^{5} \mathrm{MSc}$ in Information Technology Management, Binary University, Malaysia \\ ${ }^{6}$ Dean, Graduate School, Binary University, Malaysia
}

\begin{abstract}
The graduate unemployment rate is one of the current issues being discussed by higher education scholars. College and university students often face unemployment after spending their valuable time and money in order to receive educational advantages. It makes them are more vulnerable to unfavourable economic conditions as those students have spent a lot of their resources while having the higher education. This paper examines the reasons and factors why fresh graduates are facing unemployment in the competitive market in Klang Vally, Malaysia. 200 data of fresh graduate was collected and analysed by SPSS20. There are several factors that explain their unemployment status, and this paper identifies each component at an individual level. With specific analysis of the unemployment phenomena, this paper provides direction for further research. The study establishes that the fresh graduates need to change their demanding attitude and at the same time, they must adopt more employability skills in order to get a job placement.
\end{abstract}

Keywords: Unemployment, Fresh graduate, Factors, Job, Malaysia

\section{Introduction}

Unemployment is an unwelcome issue that may occur in every country around the world. As long, the person is involved in the labour market, he or she may one day become unemployed (Razak et al., 2014). If an unemployment issue is not resolved, the contribution to the problems of the unemployed graduates, nation, society and even the country will certainly grow. Furthermore, if the nation's unemployment continues to be severed, riots and insurgency will be happening across the country and uncertain the country trading. A significant lost towards the nation will arise due to this 
INTERNATIONAL JOURNAL OF ACADEMIC RESEARCH IN BUSINESS AND SOCIAL SCIENCES Vol. 8, No. 9, Sept. 2018, E-ISSN: 2222-6990 @ 2018 HRMARS

dangerous problem (Hanapi and Nordin, 2013). Malaysia is a rapidly developing country. It is highly open, upper middle income economy in the continent of Asia. Malaysian economy had been decreasing at GDP annual growth rate from 6.3\% in April 2014 to 4.2\% in April 2016 (Department of Statistics, 2016). Nevertheless, the increase of the population grows faster than the employment opportunities that generated in the market (Wardhana et al., 2013). Therefore, it can be considered as a reason of unemployment. According to the definition of the Malaysia Labour Force Survey, the unemployed includes a person who is willing to work, but unable to obtain a job in a certain period of time (Ismail, 2011). A high percentage of unemployment usually occurs during the economic recession where the labour supply exceeds the demand in the market. There exist many other factors within a country which may affect the unemployment rate, such as company downsizing, merger or acquisition, changes in technology, foreign competition, and job outsourcing to other countries (Wardhana et al., 2013)

A study done by the UNESCO (2012), stated that in the year 2010 the worldwide unemployment rate has been increased to $6.2 \%$ compared to $5.6 \%$ in the year 2007. Because of this, it has contributed to a highly competitive environment for younger people between the age of 15 - 24 years. In Malaysia, the unemployment problem has been a very observable phenomenon.

In Malaysia, the unemployment rate is at 3.5\% in March 2016 compared to 3.4\% in the previous three months (Department of Statistics, 2016). According to the Department of Statistics (2016), in December, the number of unemployed rose to 478,100 compared to 453,300 in the earlier month. Furthermore, last year the unemployed is totalled of 432,100 (Najib, 2016) and the labour force participation rate came in at 67.8\% in December, up from $67.7 \%$ in November (Najib, 2016).

According to the (Aina, 2017) reported that the World Bank said a high percent of jobless youth contributes to the overall unemployment in Malaysia. It includes the fresh graduates. In addition, the News Strait Times stated the Ministry of Higher Education said, a quarter of all graduates in 2012 have not obtained employment at the time of graduation, and the World Bank finds that in 2012 almost $1 / 5$ degree holders below the age of 25 were unemployed. Unfortunately, a large portion of the unemployed graduates are from the study field of Social Science, Business and Law with $39.4 \%$, followed by Engineering, Manufacturing and Construction with $21.7 \%$ and Science, Mathematics and Computing with 17.9 \% (Razak et al., 2014). So, this displays that there is an unemployment problem among fresh graduates in Malaysia that need to be addressed. Additionally, the World Bank advised that Malaysia needs to identify the mismatch in skills development and make a performance feedback tool between the educational institutions and the industry by enhancing the employability skills among the youth (Aina, 2017).

Malaysian universities, public or private higher institutions produce a large number of graduates, but the proportion of the graduates acquire a job is astonishingly low. The total number of enrolments of students in the higher institutions had been increased to 1,134,134 in the year 2010 (Rahman, 2016) compared to 576,439 in 2002 (Ismail, 2011). This issue is a serious concern as it regards the image of the education system in Malaysia as well as may inhibit Malaysia's aspiration to become a developed economic country by the end of this decade (Shamsuddin et al., 2013). Hence, a rise in the unemployment rate may donate to an escalation in the law-breaking rate. 
INTERNATIONAL JOURNAL OF ACADEMIC RESEARCH IN BUSINESS AND SOCIAL SCIENCES Vol. 8, No. 9, Sept. 2018, E-ISSN: 2222-6990 @ 2018 HRMARS

\section{Literature Review: Factors of Unemployment}

There are numerous factors contributing to unemployment among the fresh graduates in Malaysia. Hanapi and Nordin (2013) states that, the lack of excellence is one of the factors that leads to the unemployment problem among the Malaysian graduates. A notable number of Malaysian employers have a negative perception towards the graduates and have stated that the graduates lack the suitable skills and qualifications which require by the industry. Moreover, the graduates fail to demonstrate a good working performance and they are poor in the aspect of employability skills. In addition, Hanapi and Nordin (2013) stated in 2002 Central Bank of Malaysia conducted a study and concluded that the international graduates have higher employability compared to the Malaysian graduates in terms of the skills which include but not limited to technical skills, problem-solving skills, communication skills, particularly in the English language.

The previous research has discovered that fresh graduates are lack of employability skills, poor understanding of the English language and communication skill and also there are too choosy about the job and at the same time they are demanding for a higher salary is the major cause of unemployment among fresh graduates (Zahiid, 2015).

The Graduate Tracer Study is maintained by the Ministry of Education. It keeps track the standing of the students of higher educational bodies six months after graduation to determine if they are working or continuing their studies, or still looking for employment. Remarks are pulled together from public and private universities and other institutions. In 2015, among 273,373 graduates, Bachelor's Degree and Diploma, $45 \%$ and $43 \%$ of all graduates, correspondingly. Among them, 53\% were reported employed, $18 \%$ decided to pursue higher studies, and $24 \%$ of graduates were still unemployed. Amongst graduates of all qualifications, Bachelor's degree-holders are the most without a job (at 27.9\%). Studies show evidence pointing to a multitude of reasons, including the keenness of graduates for the world of work, insufficient job creation for some fields, and the lasting implications of socioeconomic backgrounds on learning and social progression.

A investigation directed by the World Bank and Talent Corporation found that, $90 \%$ organizations agree that university graduates should have received lot more industrial training by the time they finish their study, and $81 \%$ others surveyed graded a major insufficiency among graduates is communication skills.

Main reason of unemployment is mismatches of skills between recent graduates and employers' demands. Soft skills are titanic factors in acquisition of entry-level graduates, and students from Malaysian universities seem to lack in those areas. Even at the early stages of recruitment, companies and educational institutes do not always match graduating students with entry level prospects.

Service centres for career are underutilised and mostly do not recognize companies' requirements. According to the TalentCorp-World Bank assessment, only half of the companies that replied to the form bargains structured internship programmes, which could help expose university students to a variety of career paths and help them develop requisite soft skills for any position.

\section{Market Condition}

Graduates are influenced by external market changes, as well as their own personal characteristics. Uncertainty contributes to the capacity of the opportunity of employment, and the job searching 
expenses work as a cost-side variable in the progression. Market conditions play a different role in affecting the employment opportunity as well.

The graduates are delicate to the oscillation of estimated return after graduation, and flexible market environments affect the anticipated outcomes as a vital element. The risk of an economic decline and policy changes also raise the level of uncertainty. Searching costs cover various indirect interactions related to job placement, as well as direct costs such as application fees.

With oscillation of the economic condition of the country, workforces face switches among employment, unemployment, and non-participation (Krof et al., 2016). The fluctuating of the economic structure and the landscape is a likely the reason for the increases of the unemployment rate in Malaysia.

\section{Foreign Worker}

Another factor contributes to the unemployment rate in Malaysia is the foreign workers as competitors for the local graduates. In Malaysia, there is a huge demand for the skilled jobs and the foreign workers are brought in to fill the required jobs. There are more than 1.7 million foreign worker in Malaysia as of 30 June ,2017 (Aina,2017) .Most of them from Indonesia, Bangladesh, Nepal, Myanmar, India etc. Locals graduates are finding difficulty to enter in the workforce.

\section{Mismatching}

Earlier economic researches have put more emphasis on formal unemployment, which derives from regular mismatching between existing jobs and workers based on job mobility and wage bargaining cost (Herz \& Van Rens, 2011). The market requires different sizes of labour forces to meet social needs and internal requirements. Graduates who have different majors want to get a job at same time, their job searching can have different outcomes depending on the demands of the market. Graduates completing education on the departments of Sciences, Literature and Social Sciences have a tendency to show higher degrees of joblessness.

Securing a job depends not only on their academic performances, but also on personal background. There is also a certain role of race, gender and socioeconomic condition in hiring an applicant (Morley, 2001). Graduates from lower-income families also show higher unemployment rates (by household income brackets). This observation holds true across qualifications.

According to a survey done by the employment agency Jobstreet.com stated that, from the employer's perception, the fresh graduates being an unrealistic request for income above RM 3,500 for their first job. On the other hand, the normal wages offered to fresh graduates are around RM 2,100 to $\mathrm{RM} 2,500$, depending on their academic qualification.

\section{Research Objective}

This study will be able to provide an answer to the following questions:

I. To identify the influencing factors of unemployment among fresh graduates in Klang Valley, Malaysia.

II. To find the relationship among educational level,graduate attributes and unemployment . 
INTERNATIONAL JOURNAL OF ACADEMIC RESEARCH IN BUSINESS AND SOCIAL SCIENCES

Vol. 8, No. 9, Sept. 2018, E-ISSN: 2222-6990 @ 2018 HRMARS

III. To determine the relationship among employability skills,job mismatch and unemployment.

\section{Research Hypotheses}

The following is a list of the hypotheses that are empirically proven in this survey.

$\mathrm{HO}$ : A change in educational level will not give a significant change to unemployment among fresh graduates.

$\mathrm{H} 1$ : A change in educational level will give a significant change to unemployment among fresh graduates.

$\mathrm{HO}$ : A change in graduate attributes will not give a significant change to unemployment among fresh graduates

$\mathrm{H} 2$ : A change in graduate attributes will give a significant change to unemployment among fresh graduates.

HO: A change in employability skills will not give a significant change to unemployment among fresh graduates

H3: A change in employability skills will give a significant change to unemployment among fresh graduates.

$\mathrm{HO}$ : A change in job mismatch will not give a significant change to unemployment among fresh graduates

H4: A change in job mismatch will give a significant change to unemployment among fresh graduates

\section{Methodology}

This research boards quantitative approach using a Self-administrated survey. The researcher used closed ended questions to gather the data. Two hundred (200) questionnaires were distributed to the fresh graduates, of which 33 were not employed due to the incompleteness of the questionnaire and disqualify for this study. So these 33 results were dismissed from the data, which ensued in a complete data set. This intends that a total of 167 completed questionnaires was received, which all fit the set standards. Therefore, only 200 fresh graduates are selected for this study and Sandelowski (1995), mentioned that around 100 - 200 sample size for quantitative research is sufficient. The researcher explains the purpose of the study and also to give detailed instructions to complete the survey. The questionnaires were collected immediately upon completion. Therefore, the purposive sampling method is applied in this research .Lastly, the researcher uses Statistical software to find out the relationship with the variables and unemployment among fresh graduates.

\section{Variables:}

Independent Variables:

Education Level, Graduates Attributes, Employability Skills, Job Mismatch

Dependent Variable:

Unemployment among fresh graduates 
INTERNATIONAL JOURNAL OF ACADEMIC RESEARCH IN BUSINESS AND SOCIAL SCIENCES

Vol. 8, No. 9, Sept. 2018, E-ISSN: 2222-6990 @ 2018 HRMARS

\section{Data Analysis}

\section{Questionnaire Findings}

The questionnaire exists out of 33 questions, of which 25 were statements were established upon the literature review and variables and 8 questions were used to determine whether or not the respondent belonged to the required sample groups.

Table 1.0: Characteristic of respondents

\begin{tabular}{|c|c|c|}
\hline & Frequency & Percentage \\
\hline \multicolumn{3}{|l|}{ Gender } \\
\hline Male & 59 & $35 \%$ \\
\hline Female & 108 & $65 \%$ \\
\hline \multicolumn{3}{|l|}{ Age } \\
\hline 20 & 6 & $3.6 \%$ \\
\hline 21 & 9 & $5.4 \%$ \\
\hline 22 & 22 & $13.2 \%$ \\
\hline 23 & 44 & $26.3 \%$ \\
\hline 24 & 45 & $26.9 \%$ \\
\hline 25 & 17 & $10.2 \%$ \\
\hline 26 & 11 & $6.6 \%$ \\
\hline 27 & 9 & $5.4 \%$ \\
\hline 28 & 3 & $1.8 \%$ \\
\hline 29 & 1 & $0.6 \%$ \\
\hline \multicolumn{3}{|l|}{ Higher Qualification } \\
\hline Diploma & 35 & $21 \%$ \\
\hline Bachelors Degree & 112 & $67.1 \%$ \\
\hline Master Degree & 16 & $9.6 \%$ \\
\hline Doctorate/Ph.D & 4 & $2.4 \%$ \\
\hline \multicolumn{3}{|l|}{ Duration of unemployment } \\
\hline Below 3 months & 73 & $44 \%$ \\
\hline 3-6 months & 69 & $41 \%$ \\
\hline 7 months - 1 Year & 25 & $15 \%$ \\
\hline \multicolumn{3}{|l|}{ Type of Institution } \\
\hline Public University or College & 75 & $52.1 \%$ \\
\hline Private University or College & 87 & $44.9 \%$ \\
\hline Polytechnics & 5 & $3 \%$ \\
\hline Others & - & - \\
\hline \multicolumn{3}{|l|}{ Field of Studies } \\
\hline Technical & 21 & $12.6 \%$ \\
\hline ICT & 11 & $6.6 \%$ \\
\hline Arts \& Social Science & 73 & $43.7 \%$ \\
\hline Science & 27 & $16.2 \%$ \\
\hline Education & 15 & $9.0 \%$ \\
\hline Others & 20 & $12.0 \%$ \\
\hline
\end{tabular}


In this section delivers a general profile of the respondents in this study. Descriptive analysis was accomplished to understand the respondent's background, such as gender, age, higher qualification, duration of unemployment, types of institution and field of studies. The table above explained the gender of respondents who took part in this survey, $65 \%$ of the respondents were female fresh graduates and $35 \%$ were male fresh graduates. This display that the unemployment seems to be more severe among the female fresh graduates than the male fresh graduates. The majority respondents aged are 24 years old (26.9\%).

On the level of education, the results show that the majority of Bachelor's Degree holders is unemployed compared to Diploma and Master's Holders. Besides that, the majority of the respondents were below 3 months of unemployment (44\%), followed by 3-6 months of unemployment (41\%) and lastly, 7 months -1 year (15\%). This indicates that the majority of unemployment were under 6 months.

The majority of the respondents were from private university or college $(52.1 \%)$, followed by public university or college (44.9\%) and lastly by polytechnics (3.0\%). This exposes that the majority of respondents are from the private university or college. As said earlier, Malaysia becomes an education hub and there are more than 200 private universities and colleges in Malaysia. This provides the opportunities to the students to further their studies in a private institution. Other than that, to study in the public institution the students need to compete with other student's because of the seat limitation, but it's different from the private institution because of there a too many of colleges and universities in Malaysia. The questionnaire also requested the respondents to indicate the field of studies. From the feedback, the majority of the respondents were from Arts and Social Science (43.7\%), followed by Science (16.2\%), Technical (12.6\%), others (12.0\%), next Education (9.0\%), and lastly, ICT (6.6\%) studies respectively. The other studies include of engineering, Islamic Banking \& Finance, Agriculture, Accountant, Banking Studies and so on. This shows that the majority of the respondents are from the Arts and Social Science. According to Razak et al. (2014), most of the unwaged ex-students are from Social Science, Business and Law studies with 39.4 \% because every year a huge number fresh graduate is produced from this field of study. This indicates that higher enrollment among students for this field of studies and find difficult to obtain a job because of higher competition among them.

\section{Analysis of Hypotheses}

To find out what is the main factor that contribute to the unemployment among fresh graduates in Klang Valley four (4) hypotheses were established for this study. The four hypotheses represent four independent variables such as Education Level, Graduates Attributes, Employability Skills and Job Mismatch which relates to dependent variable unemployment among fresh graduates. 
INTERNATIONAL JOURNAL OF ACADEMIC RESEARCH IN BUSINESS AND SOCIAL SCIENCES

Vol. 8, No. 9, Sept. 2018, E-ISSN: 2222-6990 @ 2018 HRMARS

\section{Education Level}

Table 2.0 : Education Level

\begin{tabular}{|l|l|l|}
\hline No & Questions & Mean \\
\hline 1 & Do you think that you are highly knowledgeable in your field & $\mathbf{2 . 6 3}$ \\
\hline 2 & The syllabus studies are unrelated to job industry & $\mathbf{3 . 0 3}$ \\
\hline 3 & I am highly qualified for the job available or jobs offered & $\mathbf{2 . 6 0}$ \\
\hline 4 & I am not qualified enough for the jobs I am seeking & $\mathbf{3 . 3 5}$ \\
\hline 5 & Too many graduates are applying for the job available. & $\mathbf{2 . 2 3}$ \\
\hline
\end{tabular}

For this independent variable the hypotheses were listed below:-

HO: A change in educational level will not give a significant change to unemployment among fresh graduates.

$\mathrm{H} 1$ : A change in educational level will give a significant change to unemployment among fresh graduates.

The result above shows that a change in educational level will not give a significant change to unemployment among fresh. It is because, the majority of the respondents in this study disagreed with 3 questions that stated above. So, this variable will not give any impact the unemployment among fresh graduates.

\section{Graduates Attributes}

Table 3.0 : Graduates Attributes

\begin{tabular}{|l|l|l|}
\hline No & Questions & Mean \\
\hline 1 & I am too choosy about the position offered by an organization & 3.49 \\
\hline 2 & I am lacking of communication skills, experience and self-motivation & 3.74 \\
\hline 3 & I am demanding for higher salary & 3.28 \\
\hline 4 & I am unable to demonstrate problem-solving ability & 3.51 \\
\hline 5 & I am unable to work in a team (group) & 3.80 \\
\hline
\end{tabular}

The above table shows how the fresh graduates would characterize themselves to the unemployment problem. Five questions have been set to find the affiliation between attributes of the graduates and 
INTERNATIONAL JOURNAL OF ACADEMIC RESEARCH IN BUSINESS AND SOCIAL SCIENCES

Vol. 8, No. 9, Sept. 2018, E-ISSN: 2222-6990 (C) 2018 HRMARS

unemployment among them. For the question above, the respondents in this study agreed with the statement that they have problem to obtain a job.

For this independent variable the hypotheses were listed below:-

$\mathrm{HO}$ : A change in graduate attributes will not give a significant change to unemployment among fresh graduates

H2: A change in graduate attributes will give a significant change to unemployment among fresh graduates.

The result above shows that a change in graduate attributes will give a significant change to unemployment among fresh. It happened because of the majority of the respondents in this study agreed with the question that stated above. So, this variable will impact the unemployment among fresh graduates.

\section{Employability Skills}

Table 4.0 : Employability Skills

\begin{tabular}{|l|l|l|}
\hline No & Questions & Mean \\
\hline 1 & I don't have the relevant working skills & 3.89 \\
\hline 2 & I have poor command in English language & 3.97 \\
\hline 3 & I have poor communication skills & 4.05 \\
\hline 4 & I am lacking of problem solving skills & 3.94 \\
\hline 5 & I am lacking of leadership qualities & $\mathbf{3 . 8 2}$ \\
\hline
\end{tabular}

The above table shows on what kind of employability skills that the fresh graduates don't haveThe majority of the respondents is agreed with the all the statement. This deliver that the fresh graduates are lacking of employability skills.

For this independent variable the hypotheses were listed below:-

HO: A change in employability skills will not give a significant change to unemployment among fresh graduates

H3: A change in employability skills will give a significant change to unemployment among fresh graduates.

The result above shows that a change in employability skills will give a significant change to unemployment among fresh. It is because, the majority of the respondents in this study agreed with all the question that stated above. Therefore, this variable will impact the unemployment among fresh graduates. 
INTERNATIONAL JOURNAL OF ACADEMIC RESEARCH IN BUSINESS AND SOCIAL SCIENCES

Vol. 8, No. 9, Sept. 2018, E-ISSN: 2222-6990 @ 2018 HRMARS

Job Mismatch

Table 5.0 : Job Mismatch

\begin{tabular}{|l|l|l|}
\hline No & Questions & Mean \\
\hline 1 & There are no appropriate or relevant jobs on offer & 3.34 \\
\hline 2 & The job that offered are irrelevant to my qualification & $\mathbf{3 . 2 1}$ \\
\hline 3 & $\begin{array}{l}\text { Is there imbalance between skill demand and skill supply in the } \\
\text { economy }\end{array}$ & $\mathbf{3 . 0 1}$ \\
\hline 4 & $\begin{array}{l}\text { Is it because of there are too many skills that required in the market } \\
\text { Is it because of overqualified skills, I find difficult to obtain a job }\end{array}$ & $\mathbf{2 . 8 5}$ \\
\hline 5 & $\mathbf{3 . 0 0}$ \\
\hline
\end{tabular}

The above questions were developed aiming to know whether there is job mismatch between the education and the industry. Five questions have been developed to find out the relationship between job mismatch and unemployment among fresh graduates. Out of five questions, for one, question "Is it because of there are too many skills that required in the market" the respondents disagreed with the above statement. For the balance four questions the respondents in this study agreed with it. Therefore, the majority of the respondents agrees with the statement. This indicates that the fresh graduates are having problem with job mismatch.

For this independent variable the hypotheses were listed below:-

HO: A change in job mismatch will not give a significant change to unemployment among fresh graduates

H4: A change in job mismatch will give a significant change to unemployment among fresh graduates.

The result above shows that a change in job mismatch will give a significant change to unemployment among fresh. It is because, the majority of the respondents in this study agreed with all the question that stated above. Therefore, this variable will impact the unemployment among fresh graduates.

\section{Findings \& Recommendations}

\section{Education Level}

The study reveals that there is less relationship between the education level and unemployment. The respondents in this study agree with the statement that they are less knowledgeable in their study field. The government of Malaysia needs to look into this issue and introduce the syllabus that related to the job industry in order to reduce the unemployment rate among the fresh graduates.

\section{Graduates Attributes}

The findings from the study discovered that graduates attributes and unemployment have a strong relationship. Almost all the respondents were strongly agreed that they were too choosy about the 
INTERNATIONAL JOURNAL OF ACADEMIC RESEARCH IN BUSINESS AND SOCIAL SCIENCES

Vol. 8, No. 9, Sept. 2018, E-ISSN: 2222-6990 @ 2018 HRMARS

position that offered by an organization. It is because, the fresh graduates want to live in comfortably life. Furthermore, the fresh graduates are exposed to a high standard of lifestyle and another reason is the high cost of living. So, this is one of the factors that have contributed to the unemployment among fresh graduates in Klang Valley, Malaysia.

\section{Employability Skills}

In general, most of the respondents strongly stated that they are lacking of the employability skills. This also goes hand in hand with the top ranked survey question, where almost all the respondents strongly agreed that they lacking of employability skills. Therefore, it is important to include elements of technical and employability skills in the curriculum for each course or field of study, which are offered in educational establishments.

\section{Job Mismatch}

The survey finding reveals that job mismatch and unemployment have a positive relationship when most of the participants strongly agreed that not many skills that required in the market and there is also an imbalance between skill demand and skill supply. But graduates who hold the greatest knowledge and skills in their study field get hired first.

-The respondents stated that because of over qualification, they find difficult to obtain a job. It is because, currently most of the graduates are pursuing their studies until Master Degree, but only certain job required higher qualification. When the fresh graduates with higher qualification they find difficult to find a job. At the same time, a study by Samah, Razali , and Basri (2015) also mentioned that few employers do not want to hire a certain youth because of there are overqualified for the position that they offered. To conclude on job mismatch, because of over qualification and too many skills that required in the market makes difficult for the fresh graduates to obtain a job.

\section{Unemployment}

-In 2005, the Minister of Human Resources, Fong Chan Onn, said that the National Economic Action Council with the association with the Department of Human Manpower had carried forth a survey and found that around 59,000 graduates were unemployed (Hanapi and Nordin, 2013). Other than that, around 30,000 graduate work in a field that did not match with their qualifications. In 2012, there is growing in job vacancies based on job vacancy resources and job placement in Peninsular Malaysia but the job vacancies are only occupied by selected workers. This designates that the unemployment occurs not because of lack job opportunity, but because of the other characteristic such as the quality of graduates.

-The majority of the respondents was strongly agreed that the employers are not willing to pay them higher. The fresh graduates demanding for higher salary are to meet the ever growing cost of living. At the same time, they need to settle their study loan and other miscellaneous expenses. By asking higher salary, the fresh graduates would be able to lead an ordinary life without any difficulties. Furthermore, the respondents are agreed that they did not prepare well for the interview and they are too choosy about the company or job that offer to them. To conclude, the findings of this research are consistent with this explanation and imply that the fresh graduates need to change their attitude in order to obtain a job. 
INTERNATIONAL JOURNAL OF ACADEMIC RESEARCH IN BUSINESS AND SOCIAL SCIENCES

Vol. 8, No. 9, Sept. 2018, E-ISSN: 2222-6990 @ 2018 HRMARS

\section{Conclusion}

This research has highlighted the factors that influence unemployment among fresh graduates in Klang Valley, Malaysia. Thereby, the objective of this study is achieved. Based on the findings, this study has demonstrated that having good grades did not assurance employment for fresh graduates in Malaysia. For that the graduates must have a good command of English and other soft skills such as leadership, communication, intelligence, analytical thinking and so on. This research provides an awareness and also guidance for the fresh graduate's problems that need to be aware of now, yet these problems will progress as fresh graduate's changes. But, not to forget, that there are many more graduates who still unemployed after many years of their graduation. At the same time, every year there will be new fresh graduates will join the list. So, the government, education institution and the individual must play a crucial role in order to reduce the unemployment rate. The results of this study provided some explanation for factor influences unemployment among fresh graduates in Klang Valley, Malaysia. The findings of this study showed that there is a strong relationship between graduate attributes, employability skills and job mismatch. Effective skills training will produce graduates who are educated and skilful before entering the working field. Likewise, it will also produce graduates with a good working ethics, proactive and able to solve problems linked to the work.

The study only focuses on a few variables which was drawn from the pilot study relatively small size of the group. Therefore, it is recommended that future researcher may expand this study by exploring more factors and variables which influences the unemployment among fresh graduates in Malaysia. Other than that, the study involving population from overall Malaysia can be conducted to evaluate the actual scenario of the research topic by representing more accurate results. Furthermore, for the future research must consider to involve qualitative method analysis. It is suggested to conduct case study analysis of the fresh graduates, which would help to find out the accurate reason of unemployment. At the same time, it is suggested to conduct the study using a bigger sample size. By conducting a detailed study, more solid information can be obtained.

\section{Corresponding Author}

Name: Mohammad Imtiaz Hossain

Affiliation: Msc in Business Economics, Faculty of Economics \& Management, University Putra Malaysia.

Country: Malaysia

Email: imtiazhossain677@gmail.com

\section{References}

Aina, N. (2017). More than 1.7 million foreign workers in Malaysia; majority from Indonesia. The New Straits Time. Retrieved from: https://www.nst.com.my/news/nation/2017/07/261418/more-17-million-foreign-workersmalaysia-majority-indonesia.

Department of Statistics Malaysia.( 2016). Labour Force and Social Statistics. Retrieved from: https://www.statistics.gov.my/index.php?r=column/cone\&menu_id=bVNhYUZZbmd3VDMrcG NxUINKSWNwUT09 rate-trend-midf-research-9495 
INTERNATIONAL JOURNAL OF ACADEMIC RESEARCH IN BUSINESS AND SOCIAL SCIENCES Vol. 8, No. 9, Sept. 2018, E-ISSN: 2222-6990 @ 2018 HRMARS

Hanapi, Z. \& Nordin, M.S. (2014). Unemployment among Malaysia graduates: Graduates' attributes, lecturers' competency and quality of education. Procedia-Social and Behavioral Sciences, 10561063.

Herz, B. \& Van Rens,T. (2011). Structural unemployment. Economics Working Papers, 1276.Retrieved from: https://www.aeaweb.org/conference/2012/retrieve.php?pdfid=98

Ismail, N.A. (2011). Graduates' characteristics and unemployment: A study among malaysian graduates. International journal of business and social science, 94-102.

Kroft, K., Lange, F., Notowidigdo, M. J., \& Katz, L. F. (2016). Long-term unemployment and the great recession: the role of composition, duration dependence, and nonparticipation. Journal of Labor Economics, 1123- 1167.

Morley, L. (2001). Producing new workers: Quality, equality and employability in higher education. Quality in Higher Education, 131-138.

Najib, A. (2016, February 18). Increase in Malaysia's unemployment rate trend - MIDF Research. Astro Awani News. Retrieved from: http://english.astroawani.com/businessnews/increasemalaysias-unemployment-rate-trend-midf-research-94955

Rahman, D. (2016, June 23). Malaysia's higher education mid-year report. The Star Online. http://www.thestar.com.my/opinion/online-exclusive/whats-yourstatus/2016/06/23/malaysiahigher-education-2016/

Razak, M.I.M., Ahmad, I. \& De Mello, G.(2014). Factors Influencing Unemployment Among Graduates in Malaysia. Lap Lambert Academic Publishing.

Shamsuddin, A., Isa, K.H.M., Aziz, M.N., Mahfol, N.Z.N.M. \& Alagari, T. (2013).Graduate unemployment :The awareness and perception of graduates towards Government's initiatives. International Journal of Business, Economics and Law,15-24.

Sandelowski, M. (1995). Sample size in qualitative research. Research in nursing \& health, 179-183.

Samah, I.H.A., Razali, R. \& Basri, H.H. (2015). Lifelong Learning And Youth Employability: Graduates In Malaysia. International Journal of Innovative Research and Advanced Studies (IJIRAS),25-29.

UNESCO (2012). Graduate employability in Asia. Asia and Pacific Regional Bureau for Education. Retrieved from: http://unesdoc.unesco.org/images/0021/002157/215706E.pdf

World Bank (2014). Malaysian Economic Monitor: Boosting Trade Competitiveness. Retrieved from http://www.worldbank.org/en/country/malaysia/publication/malaysia-economic-monitorjune-2014

Wardhana, F.S., Azizan, K.A., Ramli, M.R.,\& Hsien, S.T.H. (2013). Unemployment Dynamic in Malaysia: Macroeconomics Paper. University of Malaya - Faculty of Business and Accountancy. Retrievedfrom:https://firmansyahshidiqwardhana.wordpress.com/2012/10/20/unemployment dynamic-in-malaysia-macroeconomics-paper/

Zahiid, S. J. (2015). PM: Poor English eroding Malaysian Graduates' self-belief. Malaymail online .Retrieved from: http://www.themalaymailonline.com/malaysia/article/pmpoor-englisheroding-malaysian-graduates-self-belief 